DOI: https://doi.org/10.15407/techned2018.04 $: \underline{014}$

\title{
A THIN ELECTROMAGNETIC SHIELD OF A COMPOSITE STRUCTURE MADE ON THE BASIS OF A MAGNETIC FLUID
}

Journal

Publisher

ISSN

Issue

Pages
Tekhnichna elektrodynamika

Institute of Electrodynamics National Academy of Science of Ukraine 1607-7970 (print), 2218-1903 (online)

No 4, 2018 (July/August)

$14-18$

\section{Authors}

V.A.Glyva ${ }^{1}$, A.D.Podoltsev ${ }^{2 \star}$, B.V.Bolibrukh ${ }^{3}$, A.V.Radionov ${ }^{4}$

1 - National Aviation University,

Kosmonavta Komarova ave., 1, Kyiv-58, 03058, Ukraine

2 - Institute of Electrodynamics National Academy of Sciences of Ukraine,

pr. Peremohy, 56, Kyiv, 03057, Ukraine,

e-mail: podol@ied.org.ua

3 - Lviv Polytechnic National University,

Stepana Bandery, 12, Lviv, 79013, Ukraine

4 - SIIE "Ferrohydrodynamica",

B. Morskaya str., 45/5, Mykolayiv, 54030, Ukraine

* ORCID ID : http://orcid.org/0000-0002-9029-9397

\section{Abstract}

A thin electromagnetic shield ( $0.25-0.50 \mathrm{~mm}$ thick) were developed, which has a composite structure and was made on a magnetic fluid deposited on a dielectric substrate. Experimental 
researches of its shielding and electromagnetic properties were carried out. It is shown that the screening coefficient of a low-frequency magnetic field for such a screen is $2.4-7.8$. The screening coefficient for an ultrahigh-frequency magnetic field is 3.0-9.3. The values of these coefficients depend on the thickness of the screen. The calculation-experimental method is proposed for the determine of the effective magnetic permeability of the composite screen material. This method is using the well-known analytical solution of the magnetostatic problem for a thin spherical shell and the results of measuring screening coefficients for a screen of spherical (or nearly spherical) shape. The obtained relative values of the magnetic permeability of the material for the case of a low-frequency magnetic field are $420-1050$. These values depend little on the thickness of the screen. References 10, figures 2, tables 2.

Key words: electromagnetic screen, composite material, magnetic fluid, screening coefficient, effective magnetic permeability.

Received: 06.03.2018

Accepted: 03.04.2018

Published:

\section{References}

1. Levchenko O.G. Levchuk V.K., Timoshenko O.N. Shielding materials and means of individual protection of the welder from magnetic fields. Avtomaticheskaia svarka. 2011. No 3. Pp. 49-55. (Rus)

2. Patil N., Velhal N. Pawar R. Puri V. Electric, magnetic and high frequence properties of screen printed ferrite-ferroelectric composite thick films on alumina substrate. Microelectronics International

2015. Iss. 32(1). Pp. 25-31.

3. Kasar V., Pawar A. Novel Approach to Electromagnetic Interference Shielding for Cell 
Phones. International Journal of Science and Research. 2014. Iss. 3. Pp. 1869-1872.

4. Singh J. Computer Generated Energy Effects on Users and Shielding Interference. Internatio nal Journal of Innovative Research in Computer and Communication Engineering . 2015. Iss.3. Pp. 10022-10027.

5. Fionov A.S., Yurkov G.Y., Popko O.V., Kosobudskii I.D., Taratanov N.A., Potemkina O.V. Polymer nanocomposites: synthesis and physical properties. Advances in Composite Materials or Medicine and Nanotechnology. Rijeka, Croatia: IN-TECH Education and Publishing, 2011. Pp. 343-364.

6. Taranov N.V., Yurkov G.Yu., Kosobudsky I.D. Synthesis of rhenium-containing nanoparticles on the surface of polytetrafluoroethylene microgranules. Vestnik Saratovskogo gosudarstvennogo tekhnicheskogo universiteta . 2010. No 44. Pp. 95-101. (Rus)

7. Bogush V.A., Borbotko T.V., Nasonov N.V. Electromagnetic radiation screens based on magnetic materials. Technologies. Constructions. Application. Minsk: Bestprint. 2016. 222 p. (Rus)

8. Glyva V., Lapshin O., Kovalenko V., Khudik M. Investigation of protective properties of electromagnetic screens based on finely divided iron and its compounds. Visti Donetskoho girnychoho instytutu

2017. No 1(40). Pp. 123 - 127. (Ukr)

9. Podoltsev A. Kucheryava I. Multiscale modeling in electrical engineering. Kiev: Institute of elektrodynamics NAS of Ukraine. 2011. 256 p. (Ukr)

10. Jackson J. Classical Electrodynamics. Moskva. Mir, 1965. 702 p. 